\title{
LEGACIES OF THE INTERNATIONAL CRIMINAL TRIBUNAL FOR THE FORMER YUGOSLAVIA
}

\author{
CONSULTATION REPORT
}

Dr Kirsten Campbell and Dr Sari Wastell

Goldsmiths College, University of London

JANUARY 2008

Research supported by the Wenner Gren Foundation, with the assistance of Goldsmiths College, University of London 


\section{LEGACIES OF THE ICTY}

\section{CONTENTS}

Introduction

Summary of key findings and recommendations

Issue 1 Developing links to the region of the former Yugoslavia

Issue 2 ICTY completion as regional transfer and capacity building

Issue 3 Mechanisms of transmission of ICTY knowledge and experience

Issue 4 The archive holdings

Issue 5 'Translation' of ICTY best practice models and decisions for the region

Issue 6 Strengthening the Rule of Law in the region

Issue 7 Mobilising the legitimacy of the ICTY

Issue 8 The legacy of the ICTY for future international criminal prosecutions 


\section{LEGACIES OF THE ICTY}

\section{CONSULTATION REPORT}

\section{INTRODUCTION}

This consultation report sets out eight key issues with related recommendations concerning the legacy of the International Criminal Tribunal for the former Yugoslavia.

To date, the 'legacy' issue has been primarily considered in terms of technical issues arising from the Tribunal's projected closure in 2010. This approach has focused upon: (1) discharging residual judicial functions, such as outstanding fugitives and requests for review of judgements; and (2) managing outstanding administrative functions, particularly in relation to the ICTY archives (see UNSC Monthly Forecast Report, December 2007). We will call this approach an 'administrative' model, in that it addresses the organisation of specific judicial and administrative aspects of the legacy issue.

This consultation report recognises that these elements of the 'legacy' issue are important. However, this approach does not fully address other critical issues that arise from the closure of the ICTY. This report identifies two further aspects of the legacy of the ICTY that have not yet been adequately addressed. These aspects can be described as 'best practice' and 'regional' issues. The 'best practice' issues concern how to transmit the experience and lessons of the ICTY to international and regional criminal justice institutions. The 'regional' issues concern how to address the political and social context of the legacy of the ICTY in the regions of the former Yugoslavia. For this reason, we suggest that the 'legacies process' is a more appropriate term to replace that of 'legacy issue'. It is important to address and integrate these different aspects of the legacies of the ICTY if these are to be significant and durable.

This report draws upon extensive fieldwork and research, including over ninety interviews, undertaken in the ICTY and the region of the former Yugoslavia from 2005-2007, and funded by the Wenner Gren Foundation and Goldsmiths College, University of London. The research has involved consultation with staff from the Office of the Prosecutor, the Registry and the Chambers at the ICTY, the Association of Defence Counsel (ICTY), staff from the Office of the Trial Prosecution, the Registry and the Chambers in the State Court of Bosnia and Herzegovina, staff from Bosnian cantonal courts, the Ministry of Justice of the Republic of Croatia, the Organisation for Security and Co-operation in Europe (Serbian and Croatian Missions), and civil society groups in the region, including victim support groups, human rights bodies, and transitional justice organisations. The research culminated in 'The Legacies of the ICTY' workshop, held in London in June 2007, which brought together key actors and stakeholders from the ICTY and the region of the former Yugoslavia. We would like to thank all those who so generously gave their time and expertise during this consultation process.

A number of issues arising out of our research have been extensively considered in other contexts, such as ICTY Outreach or regional stabilisation. Many of these concerns are also the subject of ongoing completion strategy work by the ICTY and the United Nations Security Council Working Group on the Ad Hoc Tribunals. However, our discussions with stakeholders from both the ICTY and the region suggested that these issues have been primarily addressed in the context of ICTY closure rather than ICTY legacy. We understand that there are significant time and resource constraints that may influence the choice of legacy strategies for both the ICTY and the United Nations Security Council. We offer these recommendations both as indicative of the concerns of stakeholders and as possible remedies for these issues. These recommendations are relevant not only to the completion strategy of the ICTY, but also to future international criminal justice institutions.

While this research has drawn upon extensive consultation with diverse stakeholders, the analysis and recommendations in this document are those of the authors. 


\section{LEGACIES OF THE ICTY}

\section{SUMMARY OF KEY ISSUES AND RECOMMENDATIONS}

This report identifies eight key issues and related recommendations in order to develop effective strategies for ICTY legacy policies.

\section{Issue 1 Developing links to the region of the former Yugoslavia}

Consultation in the region should be undertaken on legacy issues. The ICTY can build further links to the region by mobilising local NGO expertise and working with seconded regional staff. The ICTY should try a high-level case in the region to link international and regional prosecutions and to build capacity.

\section{Issue 2 ICTY completion as regional transfer and capacity building}

Important elements of regional transfer and capacity policies should include further efforts to build on existing legal and judicial networks and identifying potential cases in ICTY archive holdings. We also recommend that there is an external institution that co-ordinates legacy issues across the ICTY and the region.

\section{Issue 3 Mechanisms of transmission of ICTY knowledge and experience}

It is recommended that best practice policy documents are developed across all ICTY organs, as well as digested judgement summaries for regional dissemination. We also recommend that the ICTY preserve its institutional records, which should be available to scholars (subject to appropriate safeguards).

\section{Issue 4 The archive holdings}

There is consensus that the archive should be kept in the region or be accessible to regional stakeholders. The ICTY should consult widely with regional stakeholders and address resource implications and the symbolic value of the archive. Additionally, it should analyse its archive in terms of the gaps in its holdings.

\section{Issue 5 'Translation' of ICTY best practice models and decisions for the region}

It is recommended that there is a report examining the appropriateness of, and challenges for, the use of ICTY decisions and procedures in regional war crimes prosecutions.

\section{Issue 6 Strengthening the Rule of Law in the region}

Further international and European support for the strengthening of links between war crimes prosecutions and the regional development of the Rule of Law is crucial. We also recommend the development of publicity materials on as yet unaddressed legacy issues.

Issue 7

Mobilising the legitimacy of the ICTY

The UN and EU should support the ongoing work of the ICTY to facilitate regional co-operation regarding war crimes prosecutions and to engage with the EU on this matter. It should also strengthen links with regional legal and civil society organisations and institutions.

\section{Issue 8 The legacy of the ICTY for future international criminal prosecutions}

The UN should develop uniform criteria for professional staff, establish an institute of international criminal justice training, and an international witness protection office. The ICTY should provide recommendations for the design of international justice institutions and their integration into transitional justice packages. 


\section{KEY ISSUES AND CHALLENGES OF THE 'LEGACY’ QUESTION}

\section{ISSUE 1 DEVELOPING LINKS BETWEEN THE ICTY AND THE REGION OF THE FORMER YUGOSLAVIA}

1.1 Throughout our two year consultation period concern was repeatedly expressed that the ICTY appears to have put 'the region' to one side in relation to legacy issues, despite the fact that the legacy is a primary concern for the peoples of the former Yugoslavia. Informants strongly believed that the ICTY should consult regional stakeholders as a priority, focusing upon civil society groups at both national and district levels.

1.2 Remaining ICTY cases, as well as current and future State and cantonal/district courts in the region, could benefit from a renewed engagement with local organisations. The ICTY has previously established a working model for such engagements, and many in the region felt the renewal of such interactions could be an important part of its legacy. Such expertise should be capitalised upon if the national jurisdictions are to continue the work begun by the ICTY.

For example, it is possible to mediate 'witness fatigue' (the situation in which some witnesses have been called multiple times in different cases), by using the expertise of various local organisations. These organisations continue to identify new victim-witnesses and to work with traumatised victim-witnesses, some of whom are now able to testify where previously they were not.

1.3 A key element of developing links between the ICTY and the region is legal capacity building. However, it was also widely observed that creating a viable legacy in this area requires more than establishing regional institutions that mirror the ICTY. Rather, it requires broad capacity building, such as the provision of systematic training and resources at lower-court levels, particularly as the majority of cases will be heard at cantonal/district levels. This includes supporting the development of an independent legal profession, particularly in the areas of the training of those undertaking defence work, and the establishment of legal aid agencies. It also involves addressing problematic regional perceptions (such as a 'legitimacy gap' for regional courts and continuing uneasiness over at the 'justice at a distance' model of the ICTY). 
RECOMMENDATION

1 A THE ICTY AND OTHER INTERNATIONAL ACTORS SHOULD UNDERTAKE REGIONAL CONSULTATION ON LEGACY ISSUES AS A MATTER OF URGENCY.

Engaging with the region, particularly with civil society groups, would shift the emphasis from administrative issues to the broader mandate and legacy of the ICTY.

1B The ICTY ShOUld COLlate AND MObilise lOCAL EXPERTISE, PARTiCularly IN RELATION TO WITNESSES, TO ASSIST ONGOING PROSECUTIONS.

A list of local organisations willing to facilitate further prosecutions should be established together with identified liaison persons. Local expertise should be seen as indispensable to the ongoing efforts to prosecute war crimes in the region as well as in the ICTY up until its closure.

1C CAPACITY BUILDing AT REgIONAL LEVEL.

Regional stakeholders would like the opportunity to work with seconded ICTY staff to share experience and expertise as equal partners. Ideally, this should happen at the State and cantonal/district levels. This includes supporting training of those undertaking defence work, as well as the establishment of legal aid agencies. Additionally, a secondment programme should be established to bring regional junior lawyers to the ICTY as part of capacity building. Such a programme would provide experience and training for the next generation of regional lawyers.

\section{D THE ICTY SHOULD TRY A HIGH-LEVEL CASE IN THE REGION}

Despite the resource challenges, the most effective strategy to address these issues is to prosecute a high-level case as an ICTY trial in a regional forum, using ICTY and regional practitioners, as it offers opportunities to:

- provide a context for capacity building rather than knowledge transfer;

- mediate legitimacy issues in relation to the ICTY's recognition of local competence;

- build regional skills and experience in relation to high-level cases; and

- address the negative legacy of the 'justice at a distance' model. 
ISSUE 2 ICTY COMPLETION AS A STRATEGY OF REGIONAL TRANSFER AND CAPACITY BUILDING

2.1 The completion strategy inevitably focuses upon ICTY closure. However, a completion strategy does not have the same focus as a legacy strategy. Informants raised concerns regarding ongoing international and regional support for national war crimes prosecutions because of the closure of the ICTY, and the withdrawal of international bodies (such as the OHR and the OSCE in some areas) due to 'regional stabilisation'.

2.2 In order to shift from a completion strategy that focuses upon the ICTY closure to a legacy strategy that connects ICTY completion to regional transfer and capacity building, we advocate developing mechanisms for co-ordinating and supporting national war crimes prosecutions.

This capacity building strategy faces three key challenges:

- how to maximise the effectiveness of the ICTY in supporting regional war crimes prosecutions until its closure;

- how to assist with the transfer of cases and suspects between national jurisdictions; and

- how to articulate ICTY 'best practice' in consultation with national jurisdictions so that those institutions can effectively use its experiences.

2.3 Informants observed that the ICTY archive contains information concerning individuals who have not been charged, but could be indicted in the future. While it was noted that there may be various reasons delaying or preventing bringing these individuals to trial in certain national jurisdictions, lists of potential cases could be prepared, referencing areas of the archive where the relevant materials can be found.

2.4 For the ICTY to have a lasting legacy of bolstering the Rule of Law in the region, it is necessary to build (rather than impose) legal cultures and institutions. The ICTY should continue to build a Rule of Law legacy particularly in the areas of:

- strengthening professional networks among the judiciary;

- reform of formal legal education (including curriculum);

- professional training of investigators, defence and prosecution counsel (particularly in the areas of human rights, humanitarian law, legal ethics, and adversarial practice); and

- ongoing judicial training (particularly in the above areas). 
While some regional training has been offered to the judiciary and prosecutors, it was noted that further provision of training for defence counsel was vital. Ideally, the judiciary, prosecutors, and defence counsel should be trained separately, but with any such training covering common elements of substantive law, legal practice, and ethics. Knowledge exchange between the ICTY judiciary, OTP, and ADC and their regional counterparts in higher- and lower-level courts is crucial. Part of an effective legacy of the ICTY would be to contribute to the building of Rule of Law cultures and institutions through these mechanisms of capacity building.

2.5 It is necessary to co-ordinate legacy programmes and the work of regional organisations and stakeholders. While ICTY Outreach supports this work, some informants felt it was not appropriate to locate these co-ordination efforts inside of the ICTY. It was suggested that an external institution should be responsible for this co-ordination, such as an organ of the United Nations (for example, the Peace Building Commission), or the European Union, (for example, building on the work of the Special and High Representative), although this would mean that the ICTY would relinquish some capacity to direct legacy strategies.

\section{RECOMMENDATION}

\section{A THE UN AND THE EU SHOULD ENABLE THE ICTY TO INTENSIFY ITS EXISTING EFFORTS TO} BUILD JUDICIAL AND LEGAL NETWORKS AND TRAINING.

The ICTY should consult with regional colleagues and professional organisations to identify a regional programme of judicial and legal specialist symposia in the areas of human rights and humanitarian law, legal ethics, and adversarial practice, and draw up recommendations regarding the development of legal and professional training for investigators, defence and prosecution counsel, and the judiciary.

2B The ICTY Should COMPILE A LIST OF POTENTIAL CASES ON THE BASIS OF ARCHIVE MATERIALS AND IDENTIFY POTENTIAL INVESTIGATIVE MATERIALS IN THE ARCHIVE.

While there were differing views as to whether the list should be passed to national jurisdictions now or at a later date, the compilation of the list of potential cases would facilitate future prosecutions.

2C THE UN OR EU SHOULD IDENTIFY AN INSTITUTION RESPONSIBLE FOR THE COORDINATION AND INTEGRATION OF REGIONAL LEGACY STRATEGIES.

This approach would strengthen regional civil society and co-ordinate the sequence and compatibility of legacy strategies. It would also support regional civil society actors, while facilitating transnational co-operation. In addition, this institution could provide a model for the future integration of international and national criminal justice. 


\section{ISSUE 3 MECHANISMS FOR THE TRANSMISSION OF THE EXPERIENCE OF THE ICTY}

3.1 Legacy issues are often conceived in either narrow administrative terms (residual judicial mechanisms to handle applications for early release, administrative structures to negotiate personnel matters, the archive and so on), or more broadly in abstract terms of law and justice (the jurisprudence, case history, adjudicated facts, the message of an 'end to impunity').

3.2 Where an administrative approach has been used, it often frames these 'administrative' issues too narrowly. This functional model has not always satisfactorily addressed ongoing postclosure issues, such as rights of the accused or needs of the victim-witnesses. For example, post-closure defence issues include early release, representation, and community reintegration, while prosecution issues include security and support.

3.3 While we recognise that important work has been done, particularly by the Transition Unit (OTP), in terms of the transfer of information, stakeholders both inside and outside of the ICTY expressed concern about the level of transfer of knowledge. The UN and EU should provide resources for ICTY staff to actively transmit their knowledge and experience.

3.4 While some of the concrete mechanisms necessary to address administrative issues have been considered, informants noted that less attention has been given to the transmission of the 'justice' aspect of the legacy. It is important that the ICTY develops the mechanisms and materials for transmitting its legal and moral legacy, as well as its institutional successes and difficulties, to national jurisdictions and other international criminal justice bodies.

3.5 The development of these concrete mechanisms is best undertaken by the ICTY, rather than external bodies. The ICTY is able to provide specific institutional perspectives and experience, and a comprehensive understanding of best practice. External bodies such as NGOs and the higher education sector are not best positioned to offer a holistic perspective and would act on an ad hoc basis through disparate institutions and agendas.

This transmission strategy should focus on areas of innovation and importance, including:

- investigation and prosecution of sexual violence and strategies of gender mainstreaming;

- procedures for investigating and prosecuting cases;

- policies for the treatment of victims and witnesses;

- development of criminal procedure to address large-scale and complex cases; and

- role of non-legal expertise, such as research, translation, and area knowledge. 
Key examples of concrete mechanisms for transmitting this aspect of the ICTY legacy include:

- handbook of Victim and Witness best practices (VWS);

- best practice and policies report on the investigation and prosecution of cases (OTP);

- trial and proceedings management report (a 'bench book' model) (Chambers and OTP);

- best practice case management (Chambers and OTP);

- best practice in defence (ADC);

- best practice in expertise, documentation, and translation (research analysts OTP);

- jurisprudence summaries for specialist and non-specialist audiences (OTP, Chambers);

- explicit sentencing policies (Chambers); and

- $\quad$ precedent forms (OTP, Chambers).

3.6 Legacy issues across the organs of the ICTY should be centrally organised and co-ordinated, and involve representatives of all three organs. Informants suggested that this could include small teams of employees to collate existing policy documents and to generate best practice documents in their specific areas of expertise and experience. There are excellent examples of best practice documentation, but they are unevenly spread across the ICTY. Therefore, consultation should take place across all three organs, and at all levels of expertise. Experienced practitioners in the ICTY need to have time made available to them to create these documents. This is becoming more urgent with the ongoing dispersal of ICTY personnel and the concomitant loss of institutional knowledge.

\section{RECOMMENDATION}

3 THE ICTY SHOULD CENTRALISE CO-ORDINATION OF SPECIALIST TEAMS:

- TO COLlate EXISTING POLICY DOCUMENTS AND TO DeVelop Best PRACTICE POLICY DOCUMENTS ACROSS ALL ORGANS; AND

- TO CREATE DIGESTED JUDGEMENT SUMMARIES.

Experienced staff, including the OTP and the ADC, require dedicated time to collate and generate these documents. 
4.1 Considerable attention has already been paid to this issue, and the United Nations has recently established the Advisory Committee on Archives ('ACA') under the direction of Justice Richard Goldstone. While the focus of previous discussions on the ICTY archive has often been upon existing documentation, important areas of institutional practice, decisions, and history are either not documented or require explanatory documentation.

4.2 Vital documentation concerning the records of the ICTY as an institution is soon to be lost due to its confidential nature. Such records are important not only in terms of institutional history, but also in terms of lessons from that history for other international criminal justice institutions.

Methods for preserving the historical record of the institution could include:

- sealing parts of the archive or particular documents for a specified period of time;

- maintenance of anonymity; or

- creating an abbreviated and redacted version of sensitive documents for inclusion in the archive.

4.3 Consideration should be given to not only existing documentation, but also to potential gaps in the records of the ICTY as an institution and to where existing records require explanatory materials. Informants noted that different sections of the ICTY have more or less complete records of their practices and decisions. They noted that certain sections of the archive also require explanatory materials, such the source and classification of documents. Consideration should be given to identifying gaps in those records, and to the creation of documents in less well-documented areas of practice.

An important gap currently concerns the documentation of defence strategies and practices. There are certain difficulties involved in archiving defence materials, and these issues should be considered, including through consultation with the ADC. This gap could also be addressed in part by ensuring the inclusion of defence pre-trial documents, interim reports, post-prosecution and end-of-trial reports. These submissions and reports provide an overview of the defence case and an understanding of the proceedings from the perspective of the defence. 
4.4 Our informants identified the location and contents of the archive as being particularly important to regional concerns. There is a widely held view that the archive should be housed in the region, notably in Sarajevo. Other informants raised the important problem of housing the archive in the region without addressing security and resource implications. There is general agreement concerning the need for the archive of original documents and artefacts to be held in a European site that is accessible for scholars from the region. However, there is also particular concern regarding access for diverse constituencies of potential users, and the symbolic 'ownership' of the archive for those in the region.

The consultative approach of the ACA is particularly important. It should strive to address the broadest group of stakeholders possible, given the diversity of opinions and interests.

Informants suggested that these issues could be addressed by distinguishing between the form and content of the archive. Content can be made more accessible by digitalisation and access to appropriate technology can be mediated by the establishment of memory centres in the region.

\section{RECOMMENDATION}

4A AN 'ACTIVE' ARCHIVE STRATEgY SHOULD BE USED TO CAPTURE EXISTING DOCUMENTATION AND TO IDENTIFY AND ADDRESS GAPS IN EXISTING DOCUMENTATION AND EXPLANATORY MATERIALS. THIS STRATEgY COULD BE LINKED TO THE DEVELOPMENT OF 'BEST PRACTICE' DOCUMENTS.

THE ICTY SHOULD PRESERVE ITS INSTITUTIONAL RECORDS AND MAKE THEM AVAILABLE TO SCHOLARS AND PRACTITIONERS (SUBJECT TO SAFEGUARDS).

4C THE ARCHIVE OF ORIGINAL DOCUMENTS AND ARTEFACTS SHOULD BE HELD IN A EUROPEAN SITE THAT IS EASILY ACCESSIBLE TO THOSE IN THE REGION. AN ELECTRONIC MIRROR ARCHIVE SHOULD BE CREATED, AND MADE ACCESSIBLE TO THOSE IN THE REGION, THROUGH THE USE OF 'MEMORY CENTRES' WHERE APPROPRIATE INFORMATION TECHNOLOGY COULD PROVIDE UNIVERSAL ACCESS.

4D THE DECISION ABOUT THE APPROPRIATE VENUE FOR HOUSING THE ORIGINAL ARCHIVE MATERIALS REQUIRES BROAD REGIONAL CONSULTATION. THE REASONING FOR THIS DECISION SHOULD BE CLEARLY EXPLAINED. 


\section{ISSUE 5 'TRANSLATION' AND THE APPROPRIATENESS OF THE BEST PRACTICE MODELS AND DECISIONS DEVELOPED IN THE ICTY FOR THE REGION}

5.1 Neither the ICTY nor 'the region' exhibit the homogeneity often attributed to them. To create an effective interface between these two entities, it is necessary to address the internal diversity and fragmentation within both the ICTY and the region.

5.2 Informants identified important issues regarding the appropriateness and translation of ICTY best practice and decisions for this diverse region. In particular, they suggested that these practices and decisions might not necessarily be appropriate to the region's distinct (and disparate) cultural, legal and historical sensibilities. Recognition of this diversity is also necessary in order to effectively use these best practice models and decisions in strengthening the Rule of Law throughout the region.

\section{RECOMMENDATION}

A REPORT CONCERNING THE APPROPRIATENESS AND TRANSLATION OF ICTY DECISIONS AND BEST PRACTICE FOR REGIONAL WAR CRIMES PROSECUTIONS SHOULD BE PRODUCED. THE REPORT SHOULD BE TRANSLATED INTO THE RELEVANT LANGUAGES FOR BROAD DISTRIBUTION AND ONGOING CONSULTATION.

Research needs to be undertaken, in consultation with both practitioners from the ICTY and the regional judicial bodies, about the appropriateness of ICTY decisions, definitions and criminal procedures in the context of the cultural, historical, and legal sensibilities of the states of the former Yugoslavia.

\section{IsSue 6 Strengthening The RULE OF LAW IN THE REgion}

6.1 Considerable progress has been made in the prosecution of war crimes and the reform of criminal codes in particular regional jurisdictions. However, informants observed that war crimes prosecutions often appear to be separate from other Rule of Law concerns. While war crimes trials are important for capacity building, they can be popularly perceived as exceptional and as an imposition of the international community. 
6.2 Informants commented that the ICTY plays an important symbolic role in the region, particularly in the strengthening of the Rule of Law. This role faces four key challenges in the context of the legacy process:

- the focus on high-level cases may exist in tension with the promotion of the Rule of Law as a shared responsibility across society;

- the ongoing need for international and regional support for linking war crimes prosecutions and the Rule of Law in the region;

- developing the institutional link between the war crimes and organised crimes sections of the $\mathrm{BiH}$ Court, which can serve as a model for other judicial systems in the region;

- developing a policy that explicitly addresses capacity building for the prosecution of war crimes prosecutions in lower-level courts, where the majority of cases will be heard.

\section{RECOMMENDATION}

6A INTERNATIONAL AND EUROPEAN SUPPORT SHOULD BE GIVEN TO STRENGTHENING LINKS BETWEEN WAR CRIMES PROSECUTIONS AND REGIONAL RULE OF LAW.

The Rule of Law can be strengthened in the region by optimising the institutional linkage between prosecutions of war crimes and organised crime.

6B THE INTERNATIONAL COMMUNITY SHOULD SUPPORT THE DEVELOPMENT OF CAPACITY BUILDING POLICIES FOR THE PROSECUTION OF WAR CRIMES PROSECUTIONS IN LOWERLEVEL COURTS.

This approach will ensure that the skills, knowledge and experience of national courts move 'down' through the judicial system.

6C The ICTY SHOUld disSEMinate EXPlanations OF PROSECUTIONS AND DECISIONS SPECIFICALLY IN THE CONTEXT OF LEGACY STRATEGIES.

The ICTY needs to legitimate and make transparent its prosecutorial decisions. The ICTY should explicitly address the focus upon high-level cases, as well as the selection of cases to develop IHL jurisprudence, and to represent particular incidences in the conflict. This will also enable the ICTY to align those decisions with ongoing efforts to strengthen the Rule of Law in the region. 


\section{ISSUE 7 MOBILISING THE LEGITIMACY OF THE ICTY}

7.1 There was a consensus among informants that the current political context of the region will shape the legacy of the ICTY. Concerns were voiced in relation to a number of issues, including the perception of a continuing 'impunity gap' in the region, renewed fears of revisionism around the conflict, and the ongoing influence of the political, intellectual, and financial elites who created the conditions for conflict. The key issue is how the ICTY can mobilise its political capital to support shifts in current political contexts that might otherwise compromise its legacy.

Three key challenges for the ICTY legacy in this regional context are to:

- shift focus from criminal prosecutions to the broader mandate;

- facilitate regional civil society organisations seeking to shift this political context, such as developing war crimes education, linking professionals inside and outside the region, and developing transitional justice mechanisms; and

- mobilise the political leverage and moral authority of the ICTY to secure greater support from the EU for legacy strategies.

\section{RECOMMENDATION}

7 THE INTERNATIONAL COMMUNITY SHOULD SUPPORT THE ICTY'S WORK TO ENHANCE REGIONAL AND EUROPEAN CO-OPERATION, AS WELL AS STRENGTHENING LINKS WITH REGIONAL ORGANISATIONS, IN ORDER TO FACILITATE SHIFTS IN THE CURRENT POLITICAL CONTEXT.

The ICTY should continue to support regional co-operation, both between the national jurisdictions and with the ICTY itself (which should continue to be seen as a pre-condition for EU accession). The ICTY could also strengthen links with regional legal and civil society organisations as part of its broader legacy mandate. 


\section{ISSUE 8 THE ICTY LEGACY FOR FUTURE INTERNATIONAL CRIMINAL PROSECUTIONS}

8.1 The important lessons and experiences of the ICTY in developing the first international criminal tribunal have not yet been fully reviewed within the ICTY itself. Informants suggested that many of the challenges faced by the ICTY of employing a hybrid legal system to try large-scale and complex international criminal cases have been recognised, but others still require review and analysis for future war crimes prosecutions.

8.2 All organs of the ICTY should contribute to such a review, since each organ will identify challenges particular to their function.

Some unique challenges facing international criminal prosecutions include:

- the high proportion of 'not guilty' pleas in war crimes prosecutions compared to national criminal proceedings;

- potential difficulties arising from defence fee-splitting;

- the possibility that some defence counsel might defend a 'cause' to the detriment of the individual defendant (which in some instances derives from the retention of defence counsel by interested regional governments);

- the challenges of ensuring equality of arms for defendants;

- difficulties of providing international protective measures for witnesses; and

- centralised international accountability for the review of perceived threats to repatriated witnesses in the case of ad hoc tribunals.

8.3 Concerns were raised regarding lack of uniformity in the criteria for appointments of staff in both regional and international institutions. It was suggested that clearer and more robust criteria for appointments from the bench downwards would contribute significantly to agreement about appropriate backgrounds and experiences of personnel (although it was recognised that certain appointments were subject to significantly different constraints). These criteria could be developed through consultation with existing staff and professional associations, drawing on both international and national experience and expertise.

8.4 Informants insisted that it was important that international criminal justice institutions learn from the successes and difficulties of the institutional design of the ICTY. They suggested that a review of 'institutional design' needs to articulate the positive and negative legacies of the ICTY. 
Such a review should consider issues such as:

- balancing the independence of prosecutor with transparency and accountability;

- the appropriate institutional role and resources necessary to integrate defence counsel;

- clarification of the relation and functions of the organs of international criminal courts;

- training across all organs of international judicial institutions in the broader cultural context of the alleged crimes and relevant legal traditions (including religious and customary legal traditions), as well as vocational training, including substantive law and criminal practice;

- the relevance of local cultural and legal knowledge and expertise for the design of future international criminal justice systems;

- the integration of non-legal expertise into all facets of the criminal prosecutions;

- building links to the community as an integral part of international criminal justice; and

- co-ordination of international criminal prosecutions with regional bodies and civil society as part of an integrated transitional justice package.

\section{RECOMMENDATION}

8A THE UN SHOULD DEVELOP UNIFORM APPOINTMENT CRITERIA FOR PROFESSIONAL STAFF.

This would include explicit and uniform international criteria for judicial, legal and other professional appointments, including regulations for appointment of defence attorneys.

8B The UN Should establish an International Witness Protection Office.

The establishment of this office would address the issue of ICTY witnesses after its closure, and would also provide a crucial service for other international criminal justice institutions.

8C The UN Should CONSUlt With the International Bar Association on the DEVELOPMENT OF AN APPROPRIATE INTERNATIONAL PROFESSIONAL ASSOCIATION FOR DEFENCE COUNSEL PRACTISING IN INTERNATIONAL CRIMINAL LAW.

8D THE UN SHOULD ESTABLISH AND RUN AN INSTITUTE FOR INTERNATIONAL CRIMINAL JUSTICE TRAINING.

A central international body would most effectively deliver specialist legal and cultural training.

8E THE ICTY SHOULD MAKE RECOMMENDATIONS REgARDING THE DESIGN OF INTERNATIONAL CRIMINAL JUSTICE INSTITUTIONS AND INTEGRATED TRANSITIONAL JUSTICE STRATEGIES.

These recommendations permit transmission of the experience of the ICTY to other international criminal courts and tribunals. 